\title{
EFEKTIVITAS TERAPI EMPATI UNTUK MENURUNKAN PERILAKU BULLYING PADA ANAK USIA SEKOLAH DASAR
}

\author{
Adinar Fatimatuzzahro ${ }^{1}$, Miftahun Nimah Suseno ${ }^{2}$, Irwanto ${ }^{3}$ \\ Program Studi Psikologi, Fakultas Ilmu Sosial dan Humaniora \\ Universitas Islam Negeri Sunan Kalijaga Yogyakarta \\ 3irw4nto@yahoo.com
}

\begin{abstract}
This study aims to determine the effectiveness of therapy in reducing bullying behavior empathy in primary school age children and to tackle issues of bullying behavior since basic education (elementary school) with empathy therapy. Subjects in this study were four students aged 10-12 years and had a propensity score bullying of moderate to high. The design was one group pre - test- post-test. Collecting data in this study was conducted using a scale of bullying behavior tendency with behavioral checklist model prepared by the researcher. Data analysis methods used by using techniques Wilcoxon Signed Rank Test to test for differences in the data score pre test, post test and post test 2 (follow up). Results of the analysis score pre test-post test showed $p$ value of 0.001 and post test 2 (follow up) $p$ value of 0.002 . It can be concluded that the therapy empathy is effective in reducing the empathy bullying behavior in children of primary school age.
\end{abstract}

\section{Keywords: Therapy Empathy, Bullying Behavior}

\section{Pendahuluan}

Bullying adalah sebuah kata dalam bahasa Inggris yaitu bully yang berarti menggertak atau dapat diartikan mengganggu orang yang lemah (Echols dan Shadily,1995). Anak-anak melakukan bullying terhadap orang lain, seperti menghina teman, meminta uang jajan teman bahkan sampai memukul apabila keinginannya tidak terpenuhi dan mengajak temannya untuk berkelahi sehingga menyebabkan dampak negatif secara fisik maupun psikologis terhadap korban (Siswati dan Widayanti, 2009). Menurut Maliki dkk dalam Hidayati (2012) perilaku bullying juga dilakukan di taman bermain (playground bullying). Anak - anak yang melakukan hal - hal tersebut dipahami oleh masyarakat sebagai anak yang bermasalah atau pembuat onar (Siswati dan Widayanti, 2009). Perilaku bullying bukanlah fenomena baru dalam dunia pendidikan. Perilaku bullying dapat dilakukan oleh siapapun, kapanpun dan dalam keadaan bagaimanapun (Goodwin, 2009). Menurut Banks dalam Saripah (2010) perilaku bullying terjadi setiap tujuh menit sekali dan mayoritas pelaku bullying melakukan perilaku bullying di lingkungan sekolah.

Menurut Sekertaris Komisi Perlindungan Anak Indonesia (KPAI) selama bulan Januari hingga April 2014 terdapat delapan catatan laporan kekerasan, yaitu dua kasus di SD (Sekolah Dasar), dua kasus di SMP (Sekolah Menengah Pertama) dan di SMA (Sekolah Menengah Atas). Data statistik KPAI menyebutkan terdapat peningkatan kasus kekerasan yang diterima oleh KPAI Nasional. Pada tahun 2010 terdapat 2.413, di tahun 2011 meningkat menjadi 2.508, di tahun 2012 meningkat 2.637, tahun 2013 bertambah tinggi yaitu 2.792 dan tahun 2014 sebanyak 3.339 kasus dan kasus kekerasan anak lainnya yang belum tercatat di KPAI . Beberapa kasus bullying sebagai bentuk kekerasan seperti penggencetan terhadap anak lain, memukul, menendang bahkan sampai menghilangkan nyawa. Hal ini menunjukkan belum tumbuhnya solidaritas, kasih sayang dan kebersamaan (Andina,2014).

Beberapa kasus bullying terjadi di beberapa wilayah di Indonesia seperti di Jakarta, Komisioner Bidang Pendidikan KPAI Susanto mengatakan bahwa terdapat kasus bullying di Sekolah Dasar di wilayah Kebayoran Lama, Jakarta Selatan. Bermula dari NAA usia 8 tahun dengan R yang berusia 8 tahun berkelahi dikarenakan $\mathrm{R}$ diejek dengan sebutan "babon dan gendut" sehingga NAA dipukul dan ditendang. NAA mengalami luka di bagian belakang kepala dan dada, dikarenakan NAA terluka cukup parah, akhirnya meninggal dunia (tribunnews;detik, 2015).

Selain itu fenomena bullying di Sekolah Dasar terjadi di Pasuruan, siswa kelas III yang bernama YW usia 9 tahun menderita sakit demam dan sakit dibagian kepala dikarenakan dipukul oleh teman - temannya di sekolah. Pengeroyokan terhadap YW dilakukan saat bermain di waktu 
istirahat. Menurut informasi yang didapatkan dari pihak sekolah, YW mengeluarkan kata - kata yang membuat teman - temannya menjadi tersinggung sehingga teman - temannya mendorong YW hingga jatuh tersungkur dan kepala YW dibenturkan oleh teman - temannya ke besi (jpp, 2015). Sedangkan di daerah Lahat CY yang berusia 9 tahun kelas V Sekolah Dasar mengaku bahwa ia ditusuk dengan pensil kayu dan pelaku mengancam akan membunuh CY. Hal ini bermula saat CY dipaksa memberikan uang jajan dan CY menolaknya sehingga ditusuk dengan pensil kemudian ditampar, dipukul dan ditendang oleh pelaku (tribunnews, 2015).

Fenomena bullying juga terjadi di Bukittinggi, seorang siswi kelas V Sekolah Dasar menjadi korban bullying berbentuk pemukulan secara berkelompok oleh teman - teman sekelasnya. Kasus tersebut bermula saat korban tidak mau memberikan uang jajan kepada salah satu pelaku sehingga membuat pelaku marah dan menganiaya korban kemudian hal tersebut diikuti oleh teman temannya yang lain (mediajurnal, 2015). Kasus bullying juga terjadi di kabupaten Bantul, Daerah Istimewa Yogyakarta. Siswa kelas V Sekolah Dasar di daerah Sanden, Bantul mengalami luka lebam si seluruh tubuhnya karena dipukul oleh teman teman sekelasnya. Korban dipukul karena tidak mau meminjamkan permainan game yang dimilikinya (okezone, 2015).

Berdasarkan observasi dan wawancara yang dilakukan oleh peneliti di sebuah Sekolah Dasar Negeri Sindet, Bantul, Daerah Istimewa Yogyakarta juga didapatkan data dari Kepala Sekolah bahwa siswa - siswi yang melakukan perilaku bullying berada di kelas III, IV dan kelas V. Berdasarkan wawancara tanggal 3 November 2015 dengan Guru Agama, kelas V yang dulunya sering melakukan perilaku bullying menjadi lebih patuh pada guru dikarenakan pernah ada seorang guru yang menangis dihadapan siswa siswi karena merasakan perilaku siswa - siswinya sudah keterlaluan. Hal tersebut membangkitkan rasa empati siswa - siswi kelas V sehingga siswa - siswi menjadi lebih bisa menghormati dan menghargai gurunya di kelas.

Menurut informasi terdapat siswa di kelas III melakukan bentuk bullying fisik seperti mencubit bahkan sampai berkelahi dan menyebabkan temannya terluka di bagian kepala (mengeluarkan darah). Di sisi lain, kelas IV dan kelas V lebih pada bentuk bullying secara verbal seperti mencemooh, mengintimidasi, mengejek pekerjaan orangtua teman yang berasal dari ekonomi yang lemah. Berdasarkan hasil observasi dan wawancara ditemukan bahwa anak yang memiliki kekuatan baik secara fisik, berasal dari keluarga yang kaya serta memiliki figur orangtua yang kuat (seperti: Ayah bersikap keras ketika di rumah) menjadikan anak membully teman- temannya. Hal tersebut didukung oleh teori Albert Bandura mengenai teori belajar sosial bahwa seseorang belajar melalui pengamatan dengan peniruan (modelling). Terdapat dua jenis pembelajaran melalui pengamatan. Pertama, belajar melalui pengamatan melalui kondisi yang dialami oleh orang lain dan yang kedua, belajar melalui pengamatan meniru model atau figur tertentu. Belajar sosial kedua ini dengan memperhatikan model yang memiliki suatu peran sebagai pemeran untuk ditiru. (Kaparang, 2013).

Masa usia perkembangan anak menurut Hurlock (1978) merupakan tahap usia berkelompok. Anak usia Sekolah Dasar pada usia perkembangan ini mencapai kematangan dalam berhubungan sosial. Anak dalam menjalin hubungan sosial pada usia perkembangan usia ini ditandai dengan adanya perluasan hubungan yaitu dengan membentuk kelompok bersama teman sebaya ataupun teman sekelas. Anak memiliki kemampuan untuk menyesuaikan diri terhadap orang lain dengan sikap membentuk kerjasama, memperhatikan kebutuhan maupun kepentingan orang lain. Menurut Yusuf (2002) anak dapat mengembangkan kemampuan bekerjasama dalam pembelajaran di sekolah dengan mengerjakan tugas berkelompok. Tugas yang dikerjakan secara berkelompok dapat memberikan kesempatan kepada anak untuk berprestasi dan mencapai tujuan bersama sehingga anak menjadi terbiasa bekerjasama, saling menghormati, bertenggang rasa serta bertanggung jawab. Hal tersebut menunjukkan bahwa anak memiliki keinginan untuk menyesuaikan diri dan disetujui kelompoknya.

Menurut Hurlock (1980) anak mewujudkan keinginan untuk dapat diterima dalam kelompok dan menjadi tidak puas apabila anak tidak bersama dalam kelompoknya. Menurut Goodwin (2009) ketika anak berada di lingkungan kelompok yang dapat menimbulkan perilaku bullying anak akan menjadi terstimulasi untuk menjadi pelaku bullying. Pada usia perkembangan anak, anak akan mempelajari perilaku agresi. Perilaku agresi yang dilakukan adalah perilaku yang dapat diterima sehingga tidak akan memperhatikan bahwa perbuatan tersebut mengandung kebenaran atau kesalahan secara keseluruhan dan akhirnya menjadi orang dewasa yang tumbuh dengan kekerasan (abusive adults).

Anak yang melakukan bullying tidak selalu memahami bahwa perilaku mereka merupakan bentuk bullying pada orang lain. Banyak kasus anak - anak yang menjadi pelaku bullying tidak memahami arti dari perilaku bullyingnya tersebut. Anak - anak dalam pergaulannya melakukan tindakan menghina, mempermalukan atau mengisolasi anak yang lain tanpa menyadari bahwa yang dilakukannya tersebut akan memberikan dampak negatif terhadap korbannya.

Proses interaksi anak usia sekolah dasar dengan orangtua maupun guru juga dapat menimbulkan perilaku bullying. Menurut Yusuf (2002) anak memiliki kemampuan untuk 
mengontrol emosi dikarenakan meniru dari orangtua maupun guru. Anak dalam proses meniru sangatlah berpengaruh. Apabila anak berada dalam lingkungan yang stabil maka emosi anak cenderung stabil. Akan tetapi, apabila kebiasaan orangtua atau guru mengekspresikan emosi kurang stabil maka emosi tersebut akan mempengaruhi anak dalam mempengaruhi sikap agresif seperti perilaku bullying.

Beberapa sebab yang menyebabkan seseorang menjadi pelaku bullying namun menurut Goodwin (2009) hal yang mendasari seorang anak menjadi pelaku bullying dikarenakan anak merasa puas ketika melakukan perilaku bullying dan keyakinan yang terdapat dalam diri pelaku bahwa perilaku bullying sah untuk dilakukan. Menurut Sari dkk (2015) pelaku merasa puas dan mengungkapkan bahwa melakukan tindakan bullying adalah hal yang menyenangkan. Menurut Usman (2013) faktor individual, hubungan keluarga, kelompok teman sebaya dan sekolah berkontribusi pada siswa dalam berperilaku bullying. Selain itu, faktor yang menjadi penyebab perilaku bullying menurut Lagerspetz, Björkquist, Berts, dan King serta Olweus adalah dikarenakan kriteria korban yang menjadi sasaran pelaku bullying seperti yang diungkapkan sebagai berikut: target perilaku bullying memiliki karakteristik sebagai korban karena terlihat lebih cemas daripada siswa secara umum (Sercombe dkk, 2013).

Perilaku bullying memiliki dampak bagi korban maupun pelaku. Penelitian yang dilakukan Prasetyo tentang bullying dan dampaknya bagi masa depan anak menunjukkan bahwa dampak negatif jangka pendek dari korban bullying ini dapat menimbulkan perasaan tidak aman, terisolasi dari lingkungan, perasaan harga diri yang rendah dan menarik diri. Sedangkan dampak negatif jangka panjang korban bullying dapat menderita masalah emosional dan perilaku, mengalami gangguan psikologis yang berat seperti depresi atau menderita stres yang dapat berakhir dengan bunuh diri (Pambudhi dkk, 2015). Menurut Goodwin (2009) anak - anak yang menjadi korban bullying memiliki perasaan bahwa dirinya tidak berharga sehingga akan selalu menyalahkan dirinya sendiri. Sedangkan pelaku bullying memiliki kekurangan dalam kemampuan empati seperti ketidakmampuan untuk menghargai emosional dan perilaku mereka terhadap perasaan orang lain. Sedangkan pada pelaku akan menumbuhkan perasaan yang arogan dan merasa lebih kuat dari yang lain sehingga pelaku menjadi pribadi yang tidak mengenal tenggang rasa dan welas asih. Padahal, hal tersebut sangat dibutuhkan dalam interaksi kelompok (Andina,2014).

Menurut Debra dalam Sari dkk (2015) mengatakan bahwa pelaku bullying adalah korban dari perilaku bullying dikarenakan pelaku yang tidak mendapatkan penanganan dan terbiasa melakukan perilaku bullying akan memiliki kecenderungan untuk terlibat dalam tindakan kekerasan bahkan perilaku negatif lainnya saat proses tumbuh kembangnya dari anak - anak menuju dewasa. Menurut Banks dalam Saripah (2010) dampak negatif perilaku bullying dapat bertahan sepanjang waktu dan korban terkadang memilih bunuh diri karena depresi yang dialaminya.

Permasalahan psikologis manusia dapat berakar dari masa lalunya, tepatnya tahap perkembangan usia anak- anak. Perilaku bullying menjadi hal yang biasa dilakukan oleh anak-anak sehingga perasaan empati dan rasa iba terhadap orang lain tidak terwujud (Goodwin, 2009). Nilainilai kebaikan yang seharusnya dimiliki oleh anakanak sebagai bibit penerus bangsa kini mulai pudar sehingga perlu adanya pengarahan dan membimbing generasi penerus bangsa khususnya anak-anak supaya menjadi generasi bangsa yang berkarakter dan berkepribadian baik.

Alasan peneliti menggunakan terapi empati dikarenakan peneliti mengupayakan kesehatan tumbuh kembang anak, baik secara fisik maupun psikologis berdasarkan peraturan Menteri Kesehatan Republik Indonesia Nomor 25 Tahun 2014 bagian kelima pasal 28 nomer 2 bahwa agar setiap anak memiliki sehat, keterampilan sosial yang baik, tumbuh dan berkembang secara harmonis dan optimal menjadi sumber daya manusia yang berkualitas. Selanjutnya bagian keenam tentang perlindungan kesehatan anak pasal 35 bahwa untuk memenuhi terjaminnya hak - hak anak, memberikan perlindungan kepada anak dari kekerasan dan diskriminasi, demi berkualitas, berakhlak mulia dan sejahtera.

Peneliti menggunakan terapi empati untuk menurunkan perilaku bullying sesuai dengan penelitian sebelumnya. Studi di luar negeri yang dilakukan oleh Stanbury dkk (2009) dari Amerika Serikat pernah melakukan penelitian tentang "The Effects Of An Empathy Building Program On Bullying Behaviour". Abstrak dalam jurnal membahas tentang pengembangan, implementasi dan menghasilkan bahwa program pembangunan empati memiliki efek positif terhadap penurunan perilaku bullying. Hasil yang lebih terdapat pada anak perempuan daripada anak laki - laki. Anak perempuan merasa lebih sensitif merasakan perasaan orang lain. Dalam penelitian Stanbury dkk (2009) subjek menjadi berkurang melakukan perilaku bullying sehingga program pembangunan empati ini mampu mengurangi perilaku bullying.

Menurut Yusuf dan Fahrudin (2012) terdapat program pencegahan bullying dengan menyampaikan pesan bahwa perilaku bullying tidak dapat diterima di sekolah. Program pencegahan bullying menggunakan kepedulian dan memahami perasaan orang lain. Penelitian selanjutnya oleh Saripah (2010) model konseling dengan empati menunjukkan hasil yang efektif untuk menurunkan 
perilaku bullying pada siswa usia sekolah dasar. Penelitian Lestari (2013) dan Saripah (2010) menggunakan aspek kognitif dan afektif dari empati dalam proses konseling sehingga secara efektif menurunkan agresi perilaku bullying. Flora (2014) menggunakan metode role playing melalui konseling kelompok dan Afriana (2013) juga menggunakan konseling kelompok untuk mengurangi perilaku bullying. Penelitian tersebut terbukti memiliki efektif mengurangi perilaku bullying ketika melibatkan faktor empati dalam proses konseling.

Beberapa penelitian menunjukkan bahwa empati menjadi faktor penting dalam proses konseling dan pekerjaan sosial lainnya. Klien yang mengalami empati dapat menghambat perilaku bullying, perilaku agresif serta kekerasan sebagai intervensi terapeutik (Ioannidou \& Konstantikaki (2008); Mercer \& Deynolds (2002); Gerdes \& Segal (2009)). Berdasarkan hal tersebut maka kemampuan empati pada seseorang memiliki korelasi terhadap perilaku bullying.

Sebuah penelitian yang dilakukan oleh Gini et.al (2006) pada 318 remaja sekolah menengah atas di North of Italia yang terdiri dari 142 perempuan dan 176 laki-laki menunjukkan bahwa pada laki-laki yang melakukan perilaku bullying secara signifikan berhubungan dengan rendahnya empati. Penelitian Sari dkk (2015) juga menunjukkan bahwa empati berkaitan dengan perilaku bullying yaitu semakin tinggi level empati seseorang maka semakin kecil kemungkinan seseorang tersebut menjadi pelaku bullying. Penelitian Sari dkk ini diperkuat oleh teori D. Jollife dan Farrington Sari dkk (2015) bahwa empati berkaitan erat dengan perilaku prososial atau perilaku menolong.

Pentingnya peneliti menggunakan terapi empati dalam penelitian ini dikarenakan beberapa penelitian menemukan bahwa empati memberikan pengaruh pada penurunan perilaku bullying. Selain itu, pada penelitian sebelumnya telah ditemukan bahwa terdapat hubungan antara empati dengan perilaku bullying. Menurut penelitian Sari dkk (2015) dan Goodwin (2009) dikarenakan pelaku yang sebenarnya memiliki rasa kasihan terhadap korban bullying mengesampingkan perasaan kasihannya terhadap korban dan lebih mementingkan kepuasaan dalam diri pelaku dalam melakukan perilaku bullying. Menurut Goodwin (2009) pelaku bullying memiliki kekurangan dalam kemampuan empati seperti ketidakmampuan untuk menghargai emosional dan perasaan orang lain sehingga tidak seharusnya perilaku bullying dipandang sebagai bagian yang normal dalam proses tumbuh kembang anak.

Selanjutnya, dikarenakan menurut beberapa penelitian seperti di Amerika pada school bullying statistics menunjukkan bahwa $85 \%$ kasus bullying tidak dihentikan oleh tenaga pendidik dan tenaga pendidikan (Andina, 2014). Menurut Hidayati
(2012) fenomena di masyarakat menunjukkan bahwa perilaku bullying terkesan "diremehkan" sehingga mengesampingkan dampak negatif bullying. Berdasarkan wawancara terhadap Guru Kelas di Sekolah Dasar Negeri Sindet, Bantul juga ditemukan bahwa guru-guru baru akan menangani kasus bullying di sekolah apabila anak sudah melakukan bentuk bullying secara fisik seperti berkelahi atau memukul temannya.

Berdasarkan penelitian yang dilakukan oleh Argiati (2010) yang meneliti tentang perilaku bullying pada siswa SMA di Yogyakarta menemukan bahwa sebagian besar siswa berusaha untuk membalas perlakuan pelaku bullying sebanyak 49,56\%, memaklumi tindakan pelaku bullying $35,4 \%$ dan diam karena merasa tidak berdaya $30,94 \%$. Sebagian anak melarikan diri dari pelaku $16,81 \%$ dan anak yang menuruti keinginan pelaku bullying karena takut diperlakukan lebih buruk sebanyak 5,31\%. Hasil penelitian menunjukkan bahwa perilaku bullying merupakan suatu masalah yang serius dengan dampak negatif yang dapat ditimbulkan. Menurut Banks dalam Saripah (2010) pelaku bullying memerlukan pendampingan lebih dari orang dewasa, agen pemerintah serta pelayanan kesehatan mental. Dengan demikian, pentingnya penanganan kasus bullying juga diperlukan dikarenakan 24,60 \% anak yang melakukan perilaku bullying tercatat sebagai pelaku kriminal di masa dewasa.

Selanjutnya, penelitian yang telah dilakukan oleh Sari dkk (2015) menemukan bahwa ketika pelaku bullying melakukan perilaku bullying, pelaku bullying mengungkapkan bahwa pelaku sebenarnya memiliki perasaan kasihan ketika melihat korbannya menangis atau panik namun karena lebih banyak merasakan perasaan senang dan puas ketika melakukan perilaku bullying maka pelaku secara berulang melakukan perilaku bullying tersebut pada waktu dan kesempatan yang berbeda. Untuk itu peneliti ingin meneliti tentang pelaku bullying khususnya anak-anak yang melakukan perilaku bullying. Peneliti menggunakan terapi empati sebagai upaya kuratif perilaku bullying pada tahap perkembangan usia anak - anak.

Oleh karena itu, berdasarkan hasil kajian literatur maka peneliti menggunakan pendekatan terapi empati untuk menurunkan perilaku bullying pada anak usia sekolah dasar.

\section{Hasil Penleitian}

Pada penelitian ini, analisis dilakukan dengan analisis kuantitatif. Pengujian hipotesis dilakukan dengan membandingkan skor pretest, posttest, dan follow up dari hasil pengukuran skala kecenderungan perilaku bullying dengan menggunakan Wilcoxon Signed-Rank Test. Hasil menunjukkan menunjukan bahwa terdapat perbedaan yang signifikan antara pre test dengan post test $(\mathrm{p}=0.001)$ dan Post test 2 (follow up) 
$(\mathrm{p}=0.002)$ sehingga terapi empati masih efektif sebagai variabel untuk menurunkan perilaku bullying.

Tabel 1

Hasil deskriptif statistik perilaku bullying pada kelompok eksperimen

\begin{tabular}{|l|c|c|}
\hline \multicolumn{1}{|c|}{ Sumber data } & $\mathbf{Z}$ & $\mathbf{p}$ (2-tailed) \\
\hline Pre test- Post test & -3.182 & 0.001 \\
\hline Pre test- Post test 2 & -3.063 & 0.002 \\
\hline Post test- Post test 2 & -7.04 & 0.482 \\
\hline
\end{tabular}

Berdasarkan uji analisis SPSS Wilcoxon Signed Rank Test menunjukan skor pre test dengan post test (28 Februari - 5 Maret 2016) terdapat perbedaan yang signifikan $(\mathrm{p}=0.001)$. Subjek penelitian yang awalnya memiliki skor kecenderungan perilaku bullying dengan kategori sedang setelah diberikan perlakuan berupa terapi empati, skor kecenderungan perilaku bullying menjadi lebih rendah atau turun. Kemudian, subjek diukur kembali skor kecenderungan perilaku bullying dengan post test 2 (Follow-up) pada tanggal $24-30$ Maret 2016 dan diperoleh skor $(\mathrm{p}=0.002)$ $(\mathrm{p}<0.05)$.

Hasil 2

Deskripsi Statistik Skor Pre test dan Post Test

\begin{tabular}{|c|c|c|c|}
\hline Keadaan & Statistika & Empirik & Hipotetik \\
\hline \multirow{4}{*}{ Pre test } & $\begin{array}{l}\text { Jumlah skor } \\
\text { maksimal }\end{array}$ & 16 & 35 \\
\hline & $\begin{array}{l}\text { Jumlah skor } \\
\text { minimal }\end{array}$ & 0 & 0 \\
\hline & Rata-rata & 9,38 & 17,5 \\
\hline & $\begin{array}{l}\text { Standar } \\
\text { deviasi }\end{array}$ & 5,714 & 5,834 \\
\hline \multirow{4}{*}{ Post test } & $\begin{array}{l}\text { Jumlah skor } \\
\text { maksimal }\end{array}$ & 5 & 35 \\
\hline & $\begin{array}{l}\text { Jumlah skor } \\
\text { minimal }\end{array}$ & 0 & 0 \\
\hline & Rata-rata & 1,31 & 17,5 \\
\hline & $\begin{array}{l}\text { Standar } \\
\text { deviasi }\end{array}$ & 1,740 & 5,834 \\
\hline \multirow{4}{*}{$\begin{array}{c}\text { Post test } \\
(\text { Follow } \\
\text { Up })\end{array}$} & $\begin{array}{l}\text { Jumlah skor } \\
\text { maksimal }\end{array}$ & 6 & 35 \\
\hline & $\begin{array}{l}\text { Jumlah skor } \\
\text { minimal }\end{array}$ & 0 & 0 \\
\hline & Rata-rata & 1,33 & 17,5 \\
\hline & $\begin{array}{l}\text { Standar } \\
\text { deviasi }\end{array}$ & 2,093 & 5,834 \\
\hline
\end{tabular}

Tabel tersebut menunjukan hasil pre test data empirik diperoleh skor terendah 0 dan skor tertinggi 16, dengan rerata empirik sebesar 9,38 dan standar deviasinya sebesar 5,714 dan data hipotetik, diperoleh skor terendah 0 dan skor tertinggi 35 , dengan rerata hipotetik sebesar 17,5 dan standar deviasinya sebesar 5,834. Sedangkan hasil post test data empirik diperoleh skor terendah 0 dan skor tertinggi 5, dengan rerata empirik sebesar 1,31 dan standar deviasinya sebesar 1,740 dan data hipotetik, diperoleh skor terendah 0 dan skor tertinggi 35 , dengan rerata hipotetik sebesar 17,5 dan standar deviasinya sebesar 5,834. Kategorisasi pada penelitian ini berdasarkan pada mean hipotetik. Selanjutnya hasil post test 2 (follow up) data empirik diperoleh skor terendah 0 dan skor tertinggi 6 , dengan rerata empirik sebesar 1,33 dan standar deviasinya sebesar 2,093 dan data hipotetik, diperoleh skor terendah 0 dan skor tertinggi 35 , dengan rerata hipotetik sebesar 17,5 dan standar deviasinya sebesar 5,834. Kategorisasi pada penelitian ini berdasarkan pada mean hipotetik Kriteria dalam mengkategorisasi yaitu rendah $[X<$ $(\mu-1 . \sigma)]$, sedang $[(\mu-1 . \sigma) \leq X<(\mu+1 . \sigma)]$, tinggi $[\mathrm{X} \geq(\mu+1 . \sigma)]$.

Berdasarkan uji analisis SPSS Wilcoxon Signed Rank Test menunjukkan skor pre test dengan post test (28 Februari - 5 Maret 2016) terdapat perbedaan yang signifikan $(\mathrm{p}=0.001)$. Subjek penelitian yang awalnya memiliki skor kecenderungan perilaku bullying dengan kategori sedang setelah diberikan perlakuan berupa terapi empati, skor kecenderungan perilaku bullying menjadi lebih rendah atau turun. Kemudian, subjek diukur kembali skor kecenderungan perilaku bullying dengan post test 2 (Follow-up) pada tanggal $24-30$ Maret 2016 dan diperoleh skor $(\mathrm{p}=0.002)$ $(\mathrm{p}<0.05)$.

Pada penelitian terapi empati, sebelum diberikan perlakuan subjek yang memiliki skor kecenderungan perilaku bullying pada kategori sedang pada subjek WDK diperoleh skor 12 pada rater guru Agama, skor 16 pada rater guru Olahraga dan skor 16 pada rater Orangtua/wali. Selanjutnya, kategori sedang pada subjek FAK diperoleh skor 13 pada rater Orangtua/wali. Selanjutnya, kategori sedang pada subjek GAY diperoleh skor 14 pada rater guru Olahraga dan skor 13 pada rater wali kelas. Selanjutnya, kategori sedang pada subjek DRW diperoleh skor 14 pada rater guru Olahraga, skor 13 dari rater Orangtua/wali dan skor 12 pada rater wali kelas. Setelah diberikan perlakuan berupa terapi empati maka skor kecenderungan perilaku bullying menjadi turun. Hal ini membuktikan bahwa hipotesis yang diajukan peneliti terbukti.

Diterimanya hipotesis dalam penelitian ini menunjukan bahwa terapi empati efektif untuk menurunkan kecenderungan perilaku bullying. Sesuai dengan hasil penelitian yang sudah dilakukan sebelumnya oleh Stanbury dkk (2009) dari Amerika Serikat yang melakukan penelitian tentang "The Effects Of An Empathy Building Program On Bullying Behaviour". Program pembangunan empati memiliki efek positif terhadap penurunan perilaku bullying. Demikian juga dengan hasil penelitian yang dilakukan oleh Yusuf dan Fahrudin (2012) terdapat program pencegahan bullying 
dengan menggunakan kepedulian dan memahami perasaan orang lain efektif untuk mencegah perilaku bullying.

Aspek - aspek terapi empati secara signifikan mampu mempengaruhi aspek kecenderungan perilaku bullying. Kemampuan untuk mengenali keberadaan orang lain (perasaan, motivasi serta niat orang lain), cara menanggapi emosional dengan baik, memprediksi dampak tindakan pada orang lain serta memahami dan menghormati pentingnya martabat orang lain mampu menurunkan aspek kecenderungan perilaku bullying yang terdiri dari aspek atau bentuk bullying fisik, bullying verbal serta bullying relasi dan sosial yang dimiliki subjek. Pada saat terapi empati, peneliti mengoperasionalkan aspek kognitif menjadi sesi kegiatan mari melihat flim kebaikan, mari memahami orang lain, inilah yang harus aku lakukan serta itu milikmu dan ini milikku. Selanjutnya, untuk aspek afektif peneliti menjabarkan menjadi sesi kegiatan aku menanggapi dirimu, mari mengenali diri, yang ku butuhkan, tanggapan baikku untukmu, empatiku, menyadari keberadaan orang lain, film kebaikan, dan mindfulness.

Pada hari pertama, peserta yang diberikan tayangan tentang film kebaikan dalam mewujudkan nilai - nilai empati dengan tindakan nyata di kehidupan sehari - hari dapat menurunkan terjadinya perilaku bullying. Melihat tayangan film kebaikan berdasarkan aspek kognitif empati tentang memahami dan menghormati martabat orang lain membuat peserta dapat lebih memahami orang lain. Film kebaikan tersebut menggambarkan untuk memahami orang lain seperti peka terhadap orang lain, menolong orang lain yang jatuh serta perilaku lain yang menggambarkan nilai - nilai empati. Hal tersebut sesuai dengan hasil observasi observer pada pelaksanaan terapi empati yaitu peserta memperhatikan setiap tayangan yang memperlihatkan nilai - nilai empati. Hal tersebut juga diperkuat dari hasil lembar "mari kita melihat film kebaikan" yang ditulis oleh peserta setelah peserta melihat film kebaikan. Hal - hal yang dituliskan oleh subjek WDK adalah menolong orang yang jatuh dari skate board, perasaan subjek WDK terharu. Subjek FAK menuliskan seperti suka memberi bagi orang yang membutuhkan, suka menolong teman dan membalas kebaikan, perasaan subjek FAK adalah sedih dan mengharukan. Selanjutnya subjek GAY menuliskan tolong menolong, membantu orang lain, saling mengasihi, membahagiakan orang lain, memberi pada orang lain, perasaan subjek GAY merasa sedih, sayang, rindu dan terharu. Pada subjek DWK menuliskan tolong menolong, mengasihi, saling membantu, saling mengasihi, perasaan subjek DWK sedih, terharu dan kangen. Menurut Damon dalam Santrock (2007) menemukan bahwa anak usia sekolah dasar dengan usia $10-12$ tahun dapat merespon kondisi atau keadaan yang dialami oleh orang lain.

Selanjutnya, sesi kegiatan pada hari pertama adalah mari memahami orang lain. Peserta saling berbagi cerita satu sama lain dengan cara mendengarkan dengan berempati. Kegiatan dalam sesi ini dapat menurunkan perilaku bullying, hal ini didukung oleh Howe (2015) yang menyatakan bahwa anak dapat memahami pengalaman yang dirasakan oleh orang lain yang tidak hanya berfokus pada diri sendiri. Pada tahapan perkembangan masa usia akhir anak - anak, empati berkembang secara luas dikarenakan anak dapat memaknai hubungannya dalam berinteraksi dengan orang lain. Hal tersebut juga didukung dari hasil observasi oleh observer bahwa peserta berusaha untuk mendengarkan peserta lainnya dalam bercerita. Hal tersebut juga didukung dari hasil lembar "mari mendengarkan kawan kita". Pada subjek WDK menuliskan pada lembar "mari mendengarkan kawan kita" yaitu bagus mendengarkan kawan, lucu (gayeng). Subjek FAK menuliskan lebih suka mendengarkan karena asik dan seru. Selanjutnya pada subjek GAY menuliskan senang karena lucu dan lebih suka mendengarkan. Pada subjek DWK menuliskan suka mendengarkan.

Pada hari kedua, terdapat kegiatan inilah yang harus aku lakukan. Pada kegiatan ini peserta dapat saling menyampaikan hal - hal atau makna tentang nilai - nilai empati yang pernah dilakukan. Berkaitan dengan hal tersebut peserta saling berbagi pengalaman dengan peserta yang lain seperti mengucapkan terimakasih apabila mendapatkan bantuan, dukungan dari orang lain. Selanjutnya mengucapkan permintaan maaf apabila melakukan kesalahan atau kekhilafan dan mengucapkan kata tolong apabila peserta membutuhkan bantuan orang lain. Dengan menggunakan hal tersebut dapat menurunkan terjadinya perilaku bullying. Hal tersebut dapat terjadi dikarenakan kegiatan tersebut memprediksi dampak tindakan kita terhadap orang lain. Pemikiran yang empatik dapat mendorong untuk bekerjasama, membangun hubungan hubungan yang memiliki kualitas baik bahkan keterhubungan yang dapat menghalangi terjadinya kekerasan seperti perilaku bullying di sekolah. (Howe, 2015). Hal tersebut juga didukung oleh hasil observasi pada observer penelitian, peserta menjalin komunikasi dan berbagi pengalamannya dengan peserta lain. Berdasarkan hasil lembar "Pengalaman dengan tiga kata ajaib dan pengalamanku" mendukung kegiatan penelitian yang dapat menurunkan perilaku bullying. Pada subjek WDK, FAK, GAY dan DWK menuliskan "Pengalaman dengan tiga kata ajaib dan pengalamanku" yaitu maaf, tolong dan terimakasih. Subjek WDK menuliskan terimakasih kepada teman yang memberikan uang saku, terimakasih kepada teman yang menolong, terimakasih kepada orangtua yang sudah memberikan makanan, terimakasih sudah 
mengantarkanku ke rumah, tolong antar saya, tolong aku bu, maaf aku tidak bisa mengantar, maaf aku sudah mengejek kamu ketika bermain, tolong tolong ada maling, maaf saya sudah merepotkan. Pada subjek FAK menuliskan terimakasih sudah diberi uang untuk beli baju dan aku ditolong saat jatuh dari sepeda, saat aku tidak bisa mandi aku ditolong dan meminta maaf saat aku melakukan kesalahan pada seseorang seperti memukul orang dan saat aku mendorong (menjatuhkan orang). Subjek GAY menuliskan terimakasih pada teman karena temanku mengasih aku uang rasanya senang, minta tolong pada teman karena aku menyuruh mengambilkan barangku dan meminta maaf karena saya membuat kesalahan. Selanjutnya, subjek DRW menuliskan terimakasih karena dikasih sesuatu sama teman, pada pak tukang aku minta tolong diambilkan barang dan minta tolong diambilkan sepeda.

Selanjutnya pada hari kedua terdapat kegiatan itu milikmu dan ini milikku. Kegiatan ini dapat menurunkan terjadinya perilaku bullying dikarenakan terdapat aspek empati yaitu memprediksi dampak tindakan pada orang lain pada kegiatan terapi ini. Menurut Hurlock (1978) berdasarkan usia perkembangannya anak dapat menyesuaikan diri terhadap orang lain dengan sikap membentuk kerjasama, memperhatikan kebutuhan maupun kepentingan orang lain. Hal tersebut didukung oleh hasil observasi observer bahwa peserta mampu merefleksikan kegiatan ini dan berusaha mengucapkan kata terimakasih pada peserta lainnya.

Pada hari ketiga, tema terapi adalah memberikan tanggapan emosional dengan baik. Pada kegiatan melibatkan aspek afektif dari empati dengan bentuk kegiatan "Aku menanggapi dirimu". Pada kegiatan ini peserta menuliskan tentang Hal hal yang tidak ingin didengar dan dilihat oleh peserta dan respon atau tanggapan peserta apabila hal yang tidak diingikan atau didengar dikatakan oleh orang lain. Kegiatan ini dapat menurunkan terjadinya perilaku bullying dikarenakan hasil observasi oleh observer kegiatan menunjukkan bahwa peserta melakukan kegiatan dengan baik, bahkan ada peserta yang mengingatkan peserta lain untuk duduk tenang dan sopan. Hal tersebut juga didukung dari hasil lembar "Bagaimana Tanggapan Kita" peserta dapat mengungkapkan apa yang dirasakan apabila ada orang lain yang melakukan hal yang tidak menyenangkan, tidak diinginkan dan lain- lain.

Selanjutnya pada hari ketiga terdapat kegiatan “ Mari mengenali diri”. Mari mengenali diri ini dapat mengungkapkan hal - hal dari peserta mengenai dirinya. Berdasarkan hasil observasi oleh observer peserta mengikuti kegiatan dengan baik. Peserta mengungkapkan sebagai diri yang memiliki sifat - sifat yang mirip dengan orang - orang di sekitarnya. Selanjutnya pada hari ketiga terdapat kegiatan "Yang Ku Butuhkan". Setelah peserta mengetahui apa yang dirasakan pada lembar "Bagaimana Memberi Tanggapan" kemudian lebih mengenali diri berdasarkan sifat - sifat dari orang orang di sekitar lingkungannya dan berusaha mengungkapkan apa yang dibutuhkan dengan cara yang baik maka hal tersebut dapat menggambarkan tema terapi dengan tanggapan emosional. Pada ketiga kegiatan tersebut berupa satu rangkaian yang diwujudkan dalam bentuk kegiatan role play yaitu "Tanggapan baikku untukmu" ini dapat menurunkan perilaku bullying yang didukung oleh Rogers dalam Howe (2015) mengungkapkan bahwa empati merupakan aspek terapi yang paling potensial dikarenakan empati bersifat membebaskan, mengonfirmasi, bahkan membawa individu untuk kembali terhubung ke dalam kelompok maupun lingkungannya. Berdasarkan hal tersebut didukung oleh hasil observasi oleh observer penelitian. Peserta melakukan hal tersebut dan berpartisipasi aktif serta peserta saling mendengarkan antar peserta.

Pada hari keempat proses pelaksanaan terapi empati terdapat kegiatan dengan tema kemampuan untuk mengenali keberadaan orang lain (perasaan, motivasi dan niat) yaitu kegiatan "Empatiku". Pada awalnya Terapis dan Co-Terapis bercerita dengan mengajak peserta untuk merasakan berada di posisi orang lain dan merefleksikan apa yang dirasakan apabila berada di posisi orang lain dan menjadi orang lain. Kemudian setelah itu peserta kembali lagi menjadi dirinya sendiri dan melihat kondisi atau situasi yang sama dengan menjadi diri sendiri. Kegiatan ini dapat menurunkan perilaku bullying. Menurut Sari dkk (2015) para pelaku bullying mengungkapkan bahwa pelaku sebenarnya memiliki perasaan kasihan ketika melihat korbannya menangis atau panik namun karena lebih banyak merasakan perasaan senang dan puas ketika melakukan perilaku bullying maka pelaku secara berulang melakukan perilaku bullying tersebut pada waktu dan kesempatan yang berbeda. Berdasarkan hal tersebut dapat diketahui bahwa pelaku sebenarnya memiliki kemampuan untuk mengenali perasaan orang lain namun kepuasan melakukan bullying terhadap korban lebih besar sehingga membuat pelaku menjadi mengesampingkan perasaan korban bullying. Hal tersebut juga didukung oleh hasil wawancara pra-terapi empati yang dilakukan oleh pneliti bahwa sebenarnya peserta memiliki perasaan kasihan dan memiliki kemampuan aspek afektif ini. Keberhasilan kegiatan ini juga didukung oleh hasil observasi observer bahwa peserta mengikuti dengan baik dan didukung dari hasil lembar " Nilai Kebaikan yang Kumiliki”. Pada subjek WDK menuliskan ketika berada di posisi orang lain yaitu menolong. Pada subjek FAK menuliskan merasa sedih, kasihan, subjek FAK akan menolong dan merawatnya. Pada subjek GAY menuliskan merasa sedih, terharu dan akan berusaha untuk membubarkan. Selanjutnya pada subjek DRW menuliskan berusaha untuk memisahkan. 
Selanjutnya, kegiatan di hari keempat dengan judul "Menyadari Keberadaan Orang Lain" peserta mengikuti dengan baik berdasarkan hasil observasi observer. Peserta dengan aktif mendengarkan dan menyimak serta memberikan respon sebagai bagian dari kemampuan berempati secara afektif. Kegiatan selanjutnya di hari keempat adalah "Film Kebaikan" peserta diberikan tayangan tentang film kebaikan dalam mewujudkan nilai - nilai empati dengan tindakan nyata di kehidupan sehari - hari dapat menurunkan terjadinya perilaku bullying. Melihat tayangan film kebaikan berdasarkan aspek afektif empati tentang mengenali keberadaan orang lain membuat peserta lebih merasakan mengenali keberadaan orang lain dengan merasakan berada di posisi orang lain. Menurut Damon dalam Santrock (2007) menemukan bahwa anak usia sekolah dasar dengan usia 10 - 12 tahun dapat merespon kondisi atau keadaan yang dialami oleh orang lain. Film kebaikan tersebut menggambarkan untuk mengenali keberadaan orang lain dengan merasakan berada di posisi orang lain seperti peka terhadap orang lain dan perilaku lain yang menggambarkan nilai - nilai empati pada aspek afektif ini. Hal tersebut sesuai dengan hasil observasi observer pada pelaksanaan terapi empati yaitu peserta memperhatikan setiap tayangan yang memperlihatkan nilai - nilai empati.

Selanjutnya, kegiatan pada hari keempat adalah mindfullness. Pada kegiatan ini peserta mengikuti dengan baik kegiatan ini berdasarkan hasil observasi observer. Setelah pelaksanaan terapi empati peserta menuliskan komitmennya setelah beberapa hari mengikuti pelaksanaan terapi empati. Pada subjek WDK menuliskan bahwa subjek akan melakukan kebaikan seperti bersikap sopan, sholat dan peduli. Pada subjek FAK menuliskan bahwa subjek akan melakukan kebaikan seperti menolong teman, membantu orangtua, bersahabat, berbagi,menolong orang yang sakit dan akan melakukan kebaikan yang telah dituliskannya karena subjek FAK menuliskan telah belajar kebaikan, senam ceria, menolong orang dan peduli selama empat hari. Selanjutnya pada subjek DRW menuliskan bahwa subjek akan mengasihi dan menolong. Pada subjek GAY menuliskan bahwa subjek telah belajar menolong, membantu, peduli, mengasihi, baik hati, bermain dan sabar. Subjek GAY juga menuliskan bahwa subjek akan rajin sholat, menolong, sabar, peduli, membantu, mengasihi, bermain, dermawan, baik hati. Pada setiap harinya setiap kegiatan yang dilaksanakan selalu merefleksikan nilai - nilai empati seperti snack untukmu, memaknai nilai empati. Berdasarkan hasil pelaksanaan terapi empati maka kegiatan dalam modul terapi empati dapat menurunkan perilaku bullying pada anak usia sekolah dasar. Hal tersebut diperoleh berdasarkan hasil dari skor behavioral checklist perilaku bullying bahwa terdapat perbedaan yang signifikan antara skor pre-test dengan post- test.
Setelah pelaksanaan terapi empati skor kecenderungan perilaku bullying pada subjek WDK dari hasil skor 12 pada rater guru Agama turun skornya menjadi 1 , skor 16 pada rater guru Olahraga turun skornya mejadi 1 , skor 16 pada rater Orangtua/wali turun skornya menjadi 5 dan skor 9 pada wali kelas turun skornya menjadi 2 . Selanjutnya, pada subjek FAK dari hasil skor 0 pada rater guru Agama tetap memiliki skor 0, skor 0 pada rater guru Olahraga tetap memiliki skor 0, skor 13 pada rater Orangtua/wali turun skornya menjadi 3 dan skor 0 pada rater wali kelas tetap memiliki skor 0 . Selanjutnya, pada subjek GAY dari hasil skor 8 pada rater guru Agama turun skornya menjadi 0, skor 14 pada rater guru Olahraga turun skornya mejadi 0 , skor 6 pada rater Orangtua/wali turun skornya menjadi 4 dan skor 13 pada wali kelas turun skornya menjadi 0. Selanjutnya, pada subjek DRW dari hasil skor 4 pada rater guru Agama turun skornya menjadi 0 , skor 14 pada rater guru Olahraga turun skornya mejadi 0 , skor 13 pada rater Orangtua/wali turun skornya menjadi 4 dan skor 12 pada wali kelas turun skornya menjadi 0 .

Masing-masing aspek dalam pelaksanaan terapi empati tersebut berperan penting dalam menurunkan kecenderungan perilaku bullying. Peneliti menggunakan tayangan atau film yang mewujudkan nilai - nilai empati pada kehidupan nyata, metode bercerita, berdiskusi, bermain peran dan bentuk kegiatan lainnya yang mendorong peserta mampu merefleksikan diri tentang nilai nilai empati. Menurut Howe (2015) munculnya empati pada anak mendorong perilaku peduli terhadap orang lain. Empati pada anak - anak dengan merenungkan pengalaman orang lain, membaca sebuah buku fiksi, bermain peran atau menyaksikan sebuah film bertemakan empati dapat menurunkan terjadinya perilaku - perilaku bullying yang dilakukan oleh siswa di Sekolah Dasar.

Damon menemukan bahwa anak dengan usia 10 tahun hingga 12 tahun mampu mengembangkan empati dengan merespon kondisi yang dialami oleh orang lain. Empati yang dimiliki oleh anak yang berusia 10 tahun hingga 12 tahun dapat terwujud dalam kepeduliannya terhadap orang lain. (Santrock, 2007). Hal tersebut didukung oleh penelitian Retnaningsih (2005) dan Fidrayani (2015) anak usia sekolah dasar menunjukkan perilaku prososial, nilai - nilai dari pengalaman empati, perilaku menolong orang lain dan bekerjasama dibandingkan pada fase usia remaja. Menurut Kagan \& Madsen oleh Retnaningsih seiring bertambahnya usia seorang anak menjadi remaja maka kompetisi pun semakin meningkat sehingga dapat menghambat keinginan seorang anak untuk menolong. Berdasarkan hal tersebut kecenderungan anak usia sekolah dasar untuk bekerjasama dalam hubungan sosialnya cenderung lebih tinggi daripada fase usia remaja. Dengan melakukan terapi empati pada anak usia sekolah dasar yang berusia 10-12 
tahun maka anak lebih mewujudkan kepedulian, menolong orang lain dan nilai - nilai kebaikan diri yang terwujud dalam empatinya.

Faktor lain yang mendukung keberhasilan penelitian, adalah penyusunan modul terapi empati yang sesuai dengan aspek empati, masukan serta saran dari pemeriksa kelayakan isi modul (manipulation check) serta hal - hal yang perlu dikurangi maupun ditambahkan dalam modul berdasarkan try out atau ujicoba modul sebelum pelaksanaan penelitian. Berdasarkan hasil tersebut, peneliti menggunakan dasar usia perkembangan usia 10 - 12 tahun dengan rentang kelas IV dan $\mathrm{V}$ dikarenakan pada tahap usia perkembangan ini proses empati muncul seperti melalui terapi, pelatihan dan praktik - praktik (Howe, 2015).

Kelemahan dalam penelitian ini :

Adapun keterbatasan dalam penelitian ini yaitu keterbatasan tempat untuk melakukan penelitian. Penelitian ini dilaksanakan di ruang perpustakaan sehingga subjek terkadang bersembunyi di balik lemari, terkadang menaiki rak buku maupun memegang buku milik pepustakaan. Selain hal tersebut, kondisi ketika istirahat bersamaan dengan kegiatan snack untukmu sehingga subjek ingin segera menyelesaikan kegiatan dan bermain di luar ruangan. Kondisi tersebut juga dikarenakan letak Perpustakaan bersebelahan dengan lapangan sekolah.

\section{Kesimpulan}

Berdasarkan hasil analisis statistik yang dilakukan, terbukti adanya perbedaan antara skor pre test, post test dan post test 2 (follow up) pada subjek dalam kelompok eksperimen. Dengan demikian dapat disimpulkan bahwa terapi empati efektif untuk menurunkan kecenderungan perilaku bullying. Berdasarkan hasil penelitian maka terapi empati dapat menanggulangi permasalahan perilaku bullying sejak pendidikan dasar (Sekolah Dasar).

\section{Saran}

Setelah melihat dan mengkaji hasil penelitian ini, peneliti memberikan beberapa saran, antara lain: 1. Kepada Orangtua dapat mencegah, menangani dan menyembuhkan kecenderungan perilaku bullying pada putra atau putrinya dengan cara menumbuhkembangkan empati dalam kehidupan sehari - hari. Orangtua dapat melakukan beberapa kegiatan sebagai upaya mengurangi tindak kencenderungan perilaku bullying pada anak, seperti memberikan sebuah tayangan video yang mewujudkan nilai - nilai empati dalam kehidupan sehingga dapat menginspirasi anak. Selain itu, menerapkan pola untuk selalu menghormati orang yang lebih tua, menghargai orang yang lebih muda dari usia anak. Beberapa hal tersebut akan lebih baik lagi untuk selalu menerapkan kata maaf apabila anak melakukan kesalahan bahkan apabila orangtua bersalah memberikan contoh pada anak dengan meminta maaf. Menghargai anak atas perbuatan yang telah dilakukannya dengan ucapan terimakasih dan mengucapkan kata minta tolong apabila membutuhkan pertolongan orang lain. Beberapa hal tersebut akan lebih memberikan efek positif berempati pada anak dalam kehidupannya.

2. Kepada Sekolah dapat menggunakan Terapi Empati dalam rangka menurunkan kecenderungan perilaku bullying pada anak. Beberapa cara yang dapat dilakukan antara lain guru mengajarkan kepada siswa untuk selalu menumbuhkankembangkan nilai nilai berempati di sekolah. Anak diberikan contoh atau figur yang mampu dicontoh oleh anak seperti menghormati orang yang lebih tua dan menghargai yang lebih muda.

3. Kepada Peneliti Selanjutnya, penelitian ini memiliki keterbatasan pada tempat. Dengan demikian, untuk peneliti selanjutnya yang ingin meneliti tentang terapi empati untuk menurunkan perilaku bullying dapat mempersiapkan tempat yang sesuai dengan kebutuhan peneliti melakukan penelitian.

\section{Daftar Pustaka}

[1] Afriana, D. (2013). Upaya Mengurangi Perilaku Bullying Di Sekolah Dengan Menggunakan Layanan Konseling Kelompok. Fakultas Keguruan Dan Ilmu Pendidikan, 1-15

[2] Andina, E. (2014). Budaya Kekerasan Antar Anak Di Sekolah Dasar. Jurnal Info Singkat Kesejahteraan Sosial, Kajian Singkat Terhadap Isu - Isu Terkini, Vol. VI (9): 9-12

[3] Argiati, H.B. (2010). Studi Kasus Perilaku Bullying pada siswa SMA di Kota Yogyakarta. Jurnal Penelitian Bappeda Kota Yogyakarta, Vol.5: 54-62

[4] Asih, G.Y \& Pratiwi, M.M.S. (2010). Perilaku Prososial Ditinjau Dari Empati Dan Kematangan Emosi. Jurnal Psikologi Universitas Muria Kudus. I, (1)

[5] Astarini, K. (2013). Hubungan Perilaku Over Protective Orangtua Dan Bullying Pada Siswa Sekolah Dasar. Educational Psychology Journal 2 (1) 
[6] Azwar, S. (1998). Metode Penelitian. Yogyakarta : Pustaka Pelajar

[12] Beane, A.L. (2008). Protect Your From Bullying : Expert Advice To Help You Recognize, Prevent, And Stop Bullying Before Your Child Gets Hurt. San Faransisco : Jossey-Bass

[13] Bullock, J.R. (2002). Bullying Among Children. Association for childhood Education International, 1-34

[14] Cole-King, A. \& Paul G. (2011). "Why Teach Compassion?": Compassionate Care : The Theory And The Reality. Journal Of Holistic Healthcare. Vol 8 (3):29-37

[15] Duyndam, J. (2013). Haptotherapy And Empathy. International Journal of Haptonomy \& Haptotherapy

[16] Echols, J dan Shadily, H. (2005). Kamus Inggris-Indonesia. Jakarta: Gramedia Pustaka Utama

[17] Fesbach, N.D and Kuchenbecker, S.Y. (1974). A Three Component Model Of Empathy. Paper Presented At The Annual Meeting Of The American Psychological Association, 1-11

[18] Fidrayani. (2015). Pengembangan Empati Pada Anak Usia Sekolah Dasar. Jurnal Seminar Psikologi dan Kemanusiaan, 125130

[19] Flora, R. (2014). Mengurangi Perilaku Bullying Kelas X-4 Melalui Pemberian Layanan Bimbingan Kelompok Teknik Role Playing Di Sma Negeri 12 Medan Tahun Ajaran 2012/ 2013. Jurnal Saintech, Vol 06 (2): 34-44
[20] Gerdes, K.E and Segal, E.A. (2009). A Social Work Model Of Empathy. Advance In Social Work, Vol 10 (2): 114-127

[21] Gini, et-al. (2006). Does Empathy Predict Adolescents' Bullying And Defending Behavior?. This Is Preprint Of An Article Accepted For Publication In Aggressive Behavior, 1-17

[22] Goodwin, D. (2009). Strategis To Deal With Bullying (Strategi Mengatasi Bullying) Alih Bahasa : Cicilia Evi Graddiplsc., M.Psi. Wellington Australia : Kidsrearch Inc

[23] Hertinjung, W.S. (2013). Bentuk - Bentuk Perilaku Bullying Di Sekolah Dasar Menggunakan Skala Bentuk Bullying. Jurnal Prosiding Seminar Nasional Parenting : 450-458

[24] Hidayati, N. (2012). Bullying Pada Anak: Analisis Dan Alternatif Solusi. Jurnal Insan, 14 (1): 41-48

[25] Howe, D. (2015). Empati Makna dan Pentingnya. Yogyakarta : Pustaka Pelajar

[26] Hurlock, E.(1980). Psikologi Perkembangan Suatu Pendekatan Sepanjang Rentang Kehidupan Edisi Kelima. Jakarta: PT Erlangga

[28] Iannotti, R.J. (1974). Empathy As A Motivator Of Altruistic Behavior. American Psychological Association Convention, 1-9

[29] Ioannidou, F and Konstantikaki, V. (2008). Empathy and Emotional Intelligence : What is it really about?. International Journal Of Caring Sciences 1 (3): 118-123 [30] Ickes, W. (1993). Empathic Accuracy. Journal of Personality 61: 4

[31] Kaparang, O. (2013). Analisa Gaya Hidup Remaja dalam Mengimitasi Budaya POP Korea melalui Televisi. Journal "Acta Diurna”. Vol.II (2) 1-15

[32] Keen, $S$ and Thomas H.B. (2006). A Theory Of Narrative Empathy. Project Muse Scholarly Journals Online By The Ohio State University. Vol 14 (3) 207-236 
[33] Kementerian Kesehatan Republik Indonesia. (2014). Upaya Kesehatan Anak: Peraturan Menteri Kesehatan Republik Indonesia Nomor 25 Tahun 2014

[34] Latipun (2011). Psikologi Eksperimen. Malang : Universitas Muhammadiyah Malang Press

[35] Lestari, D. (2013). Menurunkan Perilaku Bullying Verbal Melalui Pendekatan Konseling Singkat Berfokus Solusi. Jurnal Pendidikan Penabur, 21-36

[36] m.detik.com/news/berita/3023297/diejekgendut-alasan-bocah-pukul-siswa-sd-dikebayoran-lama-hingga-tewas diunduh 3 November 2015 pukul 05.58 WIB

[37] m.jpnn.com/news.php?id-273792 diunduh 3 November 2015 pukul 05.32 WIB

[38] Maliki, A.E., dkk. (2009) Bullying Problems Among School Children. Journal Hum Ecol, 25 (3): 209-213

[39] Margono, G. (2013). Analisis Faktor Konfirmatori Guna Mengestimasi Reliabilitas Multidimensi. Jurnal Seminar Nasional Sains dan Teknologi V Lembaga Penelitian Universitas Lampung, 1-18

[40] Matthiesen, S. B and Stale, E. (2007). Perpetrators And Targets Of Bullying At Work: Role Stress And Individual Difference. Journal Violence And Victims, 22 (6): 735-753

[41] Mercer, S.W and Reynolds, W.J. (2002). Empathy And Quality Of Care. British Journal Of General Practice, 52: 9-13

[42] Merrell, K.W \& Isava, D.M. (2008). How Effective Are School Bullying Intervention Programs? A Meta-Analysis Of Intervention Research. Apa School Psychology Quarterly, 23 (1):26-42

[43] Milsom, A., \& Gallo, L.L (2006) Bullying In Middle School :Prevention And Intervention. Middle School Journal, 37:3, 12-19

[44] Murphy, A. G.(2009). Character Education : Dealing With Bullying. New York: Chelsea House Publishers

news.okezone.com/read/2014/12/17/340/1 080280/seorang-siswa-sd-dikeroyok-12- temannya diunduh 3 November 2015 pukul 06.15 WIB

[46] Ozkan, Y dan Cifci, G.E. (2009). The Effect Of Empathy Level On Peer Bullying In Schools.Humanity \& Social Sciences Journal. 4 (1):31-38

Palembang.tribunnews.com/2014/12/15/si swi-sd-korban-bullying-diancam-dibunuh diunduh 3 November 2015 pukul 05.45 WIB

[48] Pambudhi Dkk. (2015). Efektivitas Group Cognitive Behavior Therapy (Gcbt) Dalam Menurunkan Kecemasan Mengahadapi Pelaku Bullying Ditinjau Dari Harga Diri Pada Korban Bullying. Jurnal JIPT, 3 (1):18-31

[49] Prasetyo, B. dan Jannah. (2012). Metode Penelitian Kuantitatif Teori dan Aplikasi. Jakarta: PT Raja Grafindo Persada

[50] Putra, W.S. (2013). 99 Permainan Edukatif Untuk Melatih Kecerdasan Dan Kreativitas Anak. Jogjakarta : Kata Hati

[51] Rachmah, D.N. (2014). Empati Pada Pelaku Bullying, Jurnal Ecopsy, 1 (2):5158

[52] Rahayu, I.T. (2009). Psikoterapi Perspektif Islam Dan Psikologi Kontemporer. Malang: UIN-Malang Press

[53] Retnaningsih. (2005). Peranan Kualitas Attachment, Usia dan Gender pada Perilaku Prososial. Proceeding Seminar Nasional Auditorium Universitas Gunadarma, 9-17

[54] Sahyani, R. Efektivitas Token Ekonomi Untuk Meningkatkan Perilaku Makan Pada Anak Yang Mengalami Sulit Makan. Universitas Ahmad Dahlan, Yogyakarta

[55] Santrock, J. W. (2007). Perkembangan Anak Jilid 1. Jakarta : Erlangga

[56] Sari H.N, Dkk. (2015). Pelatihan Meningkatkan Empati Melalui Psikoedukasi Kepada Pelaku Bullying Sebagai Upaya Untuk Mengurangi Bullying Di Sekolah Menengah Pertama. Jurnal Magister Psikologi Profesi, Fakultas Psikologi Universitas Padjajaran, 1-16 
[57] Saripah, I. (2010). Model Konseling Kognitif Perilaku Untuk Menanggulangi Bullying Siswa. Proceedings of The $4^{\text {th }}$ International Conference On Teacher Education : Join Conference Upi \&Upsi Bandung, Indonesia 720-726

[58] Sercombe and Donnelly,B. (2013). Bullying And Agency : Definition, Intervention, And Ethics. Journal Of Youth Studies (Routledge Taylor \& Francis Group), 16 (4) :491-502

[59] Siswati \& Widayanti. (2009). Fenomena Bullying Di Sekolah Dasar Negeri Di Semarang:Sebuah Studi Deskriptif. Jurnal Psikologi Undip, 5 (2)

[60] Stanbury, et-al. (2009). The Effect Of An Empathy Building Program On Bullying Behavior The Canadian Journal of Psychiatry, 48: 577-582

[61] Stueber, K.R. (2006). Rediscovering Empathy. London : The Mit Press

[62] Suseno, M.N. (2012). Modul Praktikum Statiska Revisi I. Laboratorium Psikologi Fakultas Ilmu Sosial dan Humaniora UIN Sunan Kalijaga

[63] Suwarto. (2007). Tingkat Kesulitan, Daya Beda dan Reliabilitas Tes menurut Teori Klasik. Jurnal Pendidikan Lembaga Penelitian Universitas Veteran Bangun Nusantara Sukoharjo, 16 (2):166-177

[64] Taufik. (2012). Empati Pendekatan Psikologi Sosial. Jakarta : Rajawali Pres

[65] Usman, I. (2013). Kepribadian, Komunikasi, Kelompok Teman Sebaya, Iklim Sekolah Dan Perilaku Bullying. Jurnal Humanitas, X (1): 49-60

[66] www.mediajurnal.com/sisiwi-sd-kelaslima-di-bukittinggi-jadi-korban-bullyingteman-sekelas-3345/ diunduh 1 November 2015 pukul 14.30 WIB

[67]

www.tribunnews.com/metropolitan/2015/ 09/19/kpai-prihatin-kasus-kekerasan-disekolah?page $=2$ diunduh 3 November 2015 pukul 06.01 WIB

[68] Yusuf, H \& Adi F. (2012). Perilaku Bullying : Asesmen Multidimensi Dan Intervensi Sosial. Jurnal Psikologi Undip, $11(2): 1-10$
[69] Yusuf, S. (2002). Psikologi Perkembangan Anak dan Remaja. Bandung: PT Remaja Rosdakarya 